${ }^{10}$ Nakano M, Worner TM, Lieber CS. Perivenular fibrosis in alcoholic liver injury: ultrastructure and histologic progression. Gastroenterology $1982 ; 83: 777-85$.

${ }^{11}$ Minato Y, Hasumura Y, Takeuchi J. The role of fat-storing cells in Disse space fibrogenesis in alcoholic liver disease. Hepatology 1983;3:559-66.

12 Palmer KR, Jenkins WJ. Impaired acetaldehyde oxidation in alcoholics. Gut $1982 ; 23: 729-33$.

13 Thomas M, Halsall BS, Peters TJ. Role of hepatic acetaldehyde dehydrogenase activity in alcoholism: demonstration of persistent reduction of cytosolic activity in abstaining patients. Lancet 1982;ii :1057-9.

${ }^{14}$ Ricciardi BR, Saunders JB, Williams R, Hopkinson DA. Hepatic ADH and ALDH isoenzymes in different racial groups and in chronic alcoholism. Pharmacol Biochem Behav 1983;18,suppl 1:61-5.

${ }^{15}$ Lewis KO, Paton A. Could superoxide cause cirrhosis ? Lancet 1982 ;ii : 188-9.

${ }^{16}$ Nakano M, Lieber CS. Ultrastructure of initial stages of perivenular fibrosis in alcohol-fed baboons. Am F Pathol 1982;106:145-55.

17 Niemela O, Risteli L, Sotaniemi EA, Risteli J. Aminoterminal propeptide of type III procollagen in serum in alcoholic liver disease. Gastroenterology $1983 ; 85: 254-9$.

${ }^{18}$ Hahn EG, Schuppan D. Collagen metabolism in liver disease. $n$ : BianchiI L, Gerok W, Landmann L, Sickinger K, Stalder GA, eds. Liver in metabolic diseases. Lancaster: MTP Press, 1983:309-23.

${ }^{19}$ Actis G, Mieli-Vergani G, Portmann B, Eddleston ALWF, Davis M, Williams R. Lymphocyte cytotoxicity to autologous hepatocytes in alcoholic liver disease. Liver 1983;3:8-12.

${ }^{20}$ Neuberger J, Crossley IR, Saunders JB, et al. Antibodies to alcoholaltered liver cell determinants in patients with alcoholic liver disease. Gut (in press).

${ }^{21}$ Barry RE. The pathogenesis of hepatitis in alcohol abuse and jejunoileal bypass. Lancet 1983; ;i :489-90.

22 Bell H, Nordhagen R. HLA antigens in alcoholics, with special reference to alcoholic cirrhosis. Scand 7 Gastroenterol $1980 ; 15: 453-6$.

${ }^{23}$ Morgan MY, Ross MGR, Ng CM, Adams DM, Thomas HC, Sherlock S, HLA-B8, immunoglobulins and antibody responses in alcohol-related liver disease. $f$ Clin Pathol $1980 ; 33: 488-92$.

${ }^{24}$ Eddleston ALWF, Davis $M$. Histocompatibility antigens in alcoholic liver disease. Br Med Bull 1982;38:13-6.
${ }^{25}$ Saunders JB, Wodak AD, Haines A, et al. Accelerated development of alcoholic cirrhosis in patients with HLA-B8. Lancet $1982 ; \mathrm{i}: 1381-4$.

${ }^{26}$ Rada RT, Knodell RG, Troup GM, Kellner R, Hermanson SM, Richards $M$. HLA antigen frequencies in cirrhotic and noncirrhotic male alcoholics: a controlled study. Alcoholism (NY) $1981 ; 5: 188-91$.

${ }^{27}$ Faizallah R, Woodrow JC, Krasner NK, Walker RJ, Morris AI. Are HLA antigens important in the development of alcohol-induced liver disease? $\mathrm{Br}$ Med f 1982;285:533-4.

${ }^{28}$ Macdougall BRD, Westaby D, Theodossi A, Dawson JL, Williams R. Increased long-term survival in variceal haemorrhage using injection sclerotherapy. Results of a controlled trial. Lancet $1982 ; \mathrm{i}: 124-7$.

${ }^{29}$ Sherlock S. Current problems in alcoholic liver disease. Alcohol and Alcoholism 1983;18:99-118.

${ }^{30}$ Orrego $\mathrm{H}$, Kalant $\mathrm{H}$, Israel $\mathrm{Y}$, et al. Effect of short-term therapy with propylthiouracil in patients with alcoholic liver disease. Gastroenterology $1979 ; 76: 105-15$.

${ }^{31}$ Hallé P, Paré P, Kaptein E, Kanel G, Redeker AG, Reynolds TB. Doubleblind, controlled trial of propylthiouracil in patients with severe acute alcoholic hepatitis. Gastroenterology 1982;82:925-31.

32 Colman JC, Morgan MY, Scheuer PJ, Sherlock S. Treatment of alcoholrelated liver disease with $(+)$-cyanidanol-3: a randomised double-blind trial. Gut 1980;21:965-9.

${ }^{33}$ World MJ, Aps EJ, Shaw GK, Thomson AD. (+)-Cyanidanol-3 for alcoholic liver disease: results of a six-month clinical trial. Alcohol and Alcoholism (in press)

${ }^{34}$ Marshall AW, Graul RS, Morgan MY, Sherlock S. Treatment of alcoholrelated liver disease with thioctic acid: a six month randomised doubleblind trial. Gut 1982;23:1088-93.

${ }^{35}$ Powell WJ Jr, Klatskin G. Duration of survival in patients with Laennec's cirrhosis. Influence of alcohol withdrawal, and possible effects of recent changes in general management of the disease. Am F Med 1968; 44:406-20.

${ }^{36}$ Wodak AD, Saunders JB, Ewusi-Mensah I, Davis M, Williams R. Severity of alcohol dependence in patients with alcoholic liver disease. Br Med F 1983;287:1420-2.

${ }^{37}$ Ewusi-Mensah I, Saunders JB, Wodak AD, Murray RM, Williams R. Psychiatric morbidity in patients with alcoholic liver disease. $\mathrm{Br} \mathrm{Med} \mathcal{J}$ $1983 ; 287$ : $1417-9$.

\title{
Risks from radioiodine treatment of thyrotoxicosis
}

British conservatism applies just as much to medicine as to anything else, and our use of radioiodine in thyroid disease has scarcely altered over the past 30 years. The time has surely come, however, to re-evaluate its risks in comparison with the alternatives. Radioiodine is suspect on three grounds: the possibilities of carcinogenesis and leukaemogenesis, genetic damage, and fetal damage.

These risks may be assessed in two ways. The first is by follow up of patients treated with radioiodine. Two very large studies have been published: 59000 patients were assessed by Pochin $^{1}$ and 36000 by Saenger et al from the cooperative North American study. ${ }^{2}$ Neither series found any excess of thyroid cancer, leukaemia, or cancer in general-indeed, there were fewer than expected cases of thyroid cancer, but the follow up period is probably still too short to support this.

The second approach is to attempt to calculate the risks as in the reports by the United Nations Scientific Committee on the Effects of Atomic Radiation. ${ }^{3}{ }^{4}$ All risks are then related to dose with conservative estimates of dosage from typical treatments with iodine-131-say, $7 \mathrm{mCi}$ or $0.25 \mathrm{GBq}$. The dose to gonad and bone marrow and the whole body dose may then be taken as about 5 and 10 rads (or cGy) respectively. ${ }^{5} 6$ The risks can then be calculated. For carcinogenesis the risks of all fatal cancer may be taken as about $10^{-4} / \mathrm{rad}$ and will therefore be about $10^{-3}$. This will be a lifetime risk with a latent period of perhaps 25 years. The risk of leukaemia will be about $2 \times 10^{-5} /$ rad and therefore only $2 \times 10^{-4}$. The chances of fatal thyroid cancer would be about $10^{-5} / \mathrm{rad}$ or about one in 10 for a radiation dose of 10000 rads. If this were correct excess cases must have been reported by now. In fact, publications world wide to 1981 contain only 26 cases, ${ }^{7}$ while there are now likely to be considerably more than one million patient years' experience. The explanation of the low risk is the very considerable reduction in the number of thyroid cells at risk: the same pattern is evident in the dose response relation seen in many animals, such as myeloid leukaemia ${ }^{8}$ and lung tumours ${ }^{9}$ in RF mice, where there is an initial rise in the incidence of the neoplasm as the dose of radiation is increased, then a peak or plateau, and, finally, a decline of incidence with higher doses.

The genetic risks are much more difficult to understand and express (at any rate, for a non-geneticist readership). The simplest way seems to be consideration of the dose which will double the "spontaneous" mutation risk, and a conservative estimate of this is about 100 rads. A typical radioiodine treatment dose will therefore increase the risk by about $5 \%$. The cause of many genetic diseases is multifactorial and any increase would be seen only after radiation of a whole population over several generations. In an individual there might be only about 20 dominant effects per million per rad of irradiation in men and a much lower risk in women. These figures should be compared with the spontaneous mutation rates for diseases such as achondroplasia and retinoblastoma, both about one in $10 .^{5}$ Furthermore, genetic risks will obviously be irrelevant unless the patient fathers or conceives a child.

The fetal risks are potentially much more serious, a significant chance of developmental abnormality coming from doses as low as 5 rads, especially in the first three months of pregnancy. The fetal thyroid does not concentrate iodine before about 12 
weeks. Pregnancy must obviously be avoided by women who have just been treated with radioiodine; and iodine is secreted in milk at about 30 times the plasma concentration.

The two alternatives to radioiodine are surgery and antithyroid drugs. The risks of surgery depend on the skill and experience of the surgeon and, to a less extent, the anaesthetist, as well as the physician who prepares the patient for operation. In the best hands mortality is between $0.1 \%$ and $0.5 \%$, and there is a $0.5 \%$ risk of damage to the laryngeal nerve. These are immediate risks from the first thyroidectomy to be contrasted with lifetime radiation risks and are likely to be higher if thyroidectomy becomes less common. Antithyroid drugs will usually not be a definitive treatment but will also carry risks, of agranulocytosis especially (possibly also about $0 \cdot 1 \%$ ), and will commonly not lead to a long term remission.

On the other hand, radioiodine is said to cause more long term hypothyroidism, with a continued incidence of $2-3 \%$ a year. There is nearly the same incidence after surgery, however, and indeed the initial chances of remission and of hypothyroidism are related to the dose of ${ }^{131} \mathrm{I}$ or the proportion of thyroid removed by the surgeon. The main disadvantage of hypothyroidism is delay in diagnosis, its treatment by thyroxine being surely one of the most trouble free treatments in medicine.

What can we conclude? Individual decisions will still have to be made by the physician concerned, who will also have to consider exophthalmos and cardiac and other risks, but since their lethal or serious risks are not dissimilar both surgery and radioiodine may now be seen as reasonable first treatments (after suitable preparation) for thyrotoxicosis at all ages. A recurrence after surgery will usually be more safely treated by radioiodine. The small mortality from good surgery is probably comparable with the long term risk of radiation carcinogenesis, yet to be shown from radioiodine. Finally, when radioiodine is used it remains very important to make quite sure that the patient is not pregnant (and women should be advised to avoid pregnancy for about 12 months-on general medical grounds) and is not lactating.

How far do these comments apply to children, in view of their long expectation of life and of the known low but definite incidence of non-lethal thyroid carcinomas after low dose $x$ ray treatment? Thyrotoxicosis is uncommon in children, but its successful treatment is difficult and hazardous by surgery or by antithyroid drugs, and high dosage radioiodine treatment is not comparable with low dose $x$ ray treatment. Even more careful consideration of the alternatives will have to be made than for adults, but radioiodine should have a place; results from it (in small numbers) have been good. ${ }^{10}$

\section{Keith E Halnan}

Director,

Department of Radiotherapy and Oncology,

Hammersmith Hospital,

London W12 0HS

${ }^{1}$ Pochin EE. Leukaemia following radioiodine treatment of thyrotoxicosis. Br Med f 1960;ii:1545-50.

2 Saenger EL, Thoma GE, Tompkins EA. Incidence of leukemia following treatment of hyperthyroidism. Preliminary report of the Cooperative Thyrotoxicosis Therapy Follow-up Study. FAMA 1968;205:855-62.

${ }^{3}$ United Nations Scientific Committee on the Effects of Atomic Radiation (UNSCEAR). Sources and effects of ionizing radiation. New York: United Nations, 1977.

4 United Nations Scientific Committee on the Effects of Atomic Radiation (UNSCEAR). Ionizing radiation: sources and biological effects. New York: United Nations, 1982

${ }^{5}$ Green M, Fisher M, Miller H, Wilson GM. Blood radiation dose after ${ }^{131}$ I treatment of thyrotoxicosis. Calculations with refereiice to leükaemia. Br Med F 1961;ii:210-5.

${ }^{6}$ Halnan KE. The metabolism of radioiodine and radiation dosage in man. Br 7 Radiol 1964;37:101-7.
' McDougall IR, Nelsen TS, Kempson RL. Papillary carcinoma of the thyroid seven years after I-131 therapy for Graves' disease. Clin $\mathrm{Nucl}$ Med $1981 ; 6: 368-71$.

* Upton AC, Randolph ML, Conklin JW, et al. Late effects of fast neutrons and gamma rays in mice as influenced by the dose rate of irradiation: induction of neoplasia. Radiat Res 1970;41:467-91.

9 Yuhas JM, Walker AE. Exposure-response curve for radiation-induced lung tumors in the mouse. Radiat Res 1973;54:261-73.

10 Safa AM, Schumacher OP, Rodriguez-Antunez A. Long-term follow-up results in children and adolescents treated with radioactive iodine for hyperthyroidism. N Engl F Med 1975;292:167-71.

\section{The treatment of myopia}

Although myopia very occasionally derives from an acquired disturbance of the eye's anatomy or refraction (as from diabetes or displacement of the lens), mainly all shortsighted people have simply inherited too long an eyeball-and many resent their dependence for clear distance vision on clumsy or unsightly spectacles or exasperating contact lenses. So it is hardly surprising that "remedies" for short sight date back to prehistory, with a new "cure" (or an old one in new clothes) reaching the headlines every few years.

By the end of the last century most of the zanier herbs and nostra of our forebears had yielded to treatments which could make a pretence of a scientific justification (calcium "to harden up a distensible sclera"; vitamins B, D, and E; proteins; thyroid extracts; placental implants; and so on). About the same time the emphasis was shifting to a more functional approach, and (since myopia normally increases during the growing years) shortsighted schoolchildren were encouraged to avoid reading (lest this should "strain" their focusing muscles) or were obliged to give it up by neutralising the accommodation with either atropine drops or convex spectacles. Indeed, the use of convex lenses is still recommended in the Far East, ${ }^{1}$ where some $60 \%$ of the population is myopic compared with $15 \%$ in Britain. These harsh restrictions along with "myope schools" (where teaching was primarily oral or on distant blackboards) had largely been abandoned in the West before the last world war, but occasional spirited advocates are still heard on the home front, such as Professor Montagu Ruben, ${ }^{2}$ who reckons that "bigger print and good lighting can help stop myopia."

Meanwhile other voices were being heard, declaring that myopia could actually be curbed, either by the constant wearing of corrective concave spectacles or else by contact lenses, whose pressure would prevent the eye elongating (they do transiently reduce the myopia by flattening the cornea, as the ancient Chinese discovered when they took to sleeping with sandbags weighing on their closed eyelids). In the 1920s this functional approach took a more positive form, when "Dr" Bates $^{3}$ declared that myopia could be arrested by exercising rather than by resting the extraocular muscles and accommodation, a technique that had a substantial boost from the testimony of Aldous Huxley. ${ }^{4}$ (Alas, he had spoken too soon, as his sight steadily worsened after his book was published.)

Since myopia is essentially the result of an anatomical defect surgery might seem to be the most straightforward solution. This approach began in Vienna in the 1890 s with Fukala ${ }^{5}$ advocating removal of the lens from highly myopic eyes (considerable hypermetropia was known to follow cataract extraction), followed by Muller ${ }^{6}$ advising a shortening of the overlong eyeball by rescetion of cquatorial strips of sclera (as had already been done for retinal detachment); but with both procedures retinal detachment was usually the sorry outcome. 